\title{
Biodegradability Kraft Paper Coated with Films Emulsified Chitosan and Palmitic Acid
}

\author{
Arlete B. Reis ${ }^{1,2,{ }^{*}, \text { Cristiana M.P. Yoshida }}{ }^{1,3}$, Elke S.D. Vilela ${ }^{4}$, Rosely S. Nascimento ${ }^{4}$, \\ Itamar S. Melo ${ }^{4}$ and Telma T. Franco ${ }^{1}$ \\ ${ }^{1}$ UNICAMP - School of Chemical Engineering State University of Campinas, UNICAMP, Zeferino Vaz \\ University City s/no CEP 13083-970, Campinas -SP/Brazil \\ ${ }^{2}$ UFVJM - Federal University of the Valleys Jequitinhonha and Mucuri, ICT - Science and Technology \\ Institute - Campus II, MGT Highway, Km 583, no. 5000, High Jacuba, CEP 39100-000 - Diamantina - MG / \\ Brazil \\ ${ }^{3}$ UNIFESP - Federal University of São Paulo - Department of Exact Sciences and Earth, Professor Arthur \\ Street-Ridel, 275, CEP 09972-270, Diadema-SP/Brazil \\ ${ }^{4}$ EMBRAPA - Environmental Microbiology Laboratory, Rodovia 340 Km 127,5, Tanquinho Velho, CEP 13820- \\ 000 PO Box 69, Jaguariúna / SP/Brazil
}

\begin{abstract}
The use of natural polymers is an alternative to polymers derived from petroleum that may reduce industrial waste and contribute to the environmental protection. Following the same reasoning, the biodegradability of paper packaging is already known for it being a product originated from cellulosic materials (cellulosic fibers). The aim of this work was to assess the process of degradation from the junction of two different materials; biopolymer and sheets of paper. This paper proposes the study of the biodegradability of chitosan film-coated Kraft paper sheets and emulsified chitosan film-coated Kraft paper sheets added with palmitic acid, both in comparison with uncoated Kraft paper sheets. The biodegradability study was conducted based on analyses of biofilm formation by Scanning Electron Microscopy (SEM), soil respiration, Gravimetry, Microbial Biomass Carbon and enzymatic soil activity and evaluation.
\end{abstract}

Keywords: Biodegradability, biopolymer, chitosan, Kraft paper, microbial biomass carbon, soil respiration, biofilm formation, enzymatic activity.

\section{INTRODUCTION}

The constant concern to elaborate products that cause minimum impact and waste generation to the environment has been subject of several studies intended to enhance environmental protection. Industries have been making efforts to obtain and/or partially replace fossil raw materials by renewable materials.

A good example of such efforts is the packaging industry that, steadily growing in the market, prioritizes the development of new technologies intended to mitigate recycling, environmental pollution and biodegradation problems, among others. Within this context, the replacement of synthetic polymers for biopolymers is an alternative reduce the use of nonrenewable materials.

Biopolymers are polymers derived from natural renewable sources and are usually biodegradable and less toxic. They can be produced by biological systems

*Address correspondence to this author at the UNICAMP - School of Chemical Engineering State University of Campinas, UNICAMP, Zeferino Vaz University City s/no CEP 13083-970, Campinas -SP/Brazil; Tel: 55-38-88049314; Fax: 55-38-35321290; E-mail: arlete.reis@ict.ufvjm.edu.br, abreys@gmail.com or synthesized whether by chemical or enzyme catalysis [1]. In addition to presenting an alternative to polymers derived from petroleum, most of them are degraded in weeks.

The biodegradability of polymers depends on the chemical and physical structure, on the chain length and on the crystalline structure [2]. The biodegradation of these polymers is usually initiated at the less crystalline parts due to the greater mobility of polymer chains, facilitating the access of microorganisms to the substrate [3]. Factors such as light, temperature, humidity, morphologic structure of the surface, $\mathrm{pH}$, among others, also influence the degradation $[4,5]$.

Polymers are considered biodegradable when degradation results from microbial activity, such as fungi, bacteria and algae, generating water, $\mathrm{CO}_{2}, \mathrm{CH}_{4}$, cellular components and other products [6]. There are several biodegradable polymers; one of them is chitosan, which consists of a linear sequence of $\beta-(1-\beta$ 4)2-acetamide-2-deoxy-D-glucose ( $\mathrm{N}$-acetylglucosamine) monomeric sugars and glucosamine from chitin deacetylation [7]. 
Chitosan is obtained from the processing of fishing industry waste by the following operations: discoloration, deproteinization and deacetylation. It is able to form resistance films, difficult to break, becoming a potential substitute for synthetic polymers in different industrial sectors, such as the packaging industry [8]. This industry has been looking for applications of significant importance due to its cationic behavior and biodegradable features [9].

The long degradation period of currently used packaging materials is a major environmental problem that encourages the conduction of studies on the application of biodegradable materials [2]. Nondegradable compounds added to the paper manufacturing process, such as synthetic polymers resistant to enzymatic and microbial action are produced worldwide. The use of non-degradable compound has been turning into a problem in which the search for solutions is based on the exploration of new packaging materials [9].

As many other industries, the pulp and paper industry has also been the target of environmental groups around the world. The environmental awareness is clear and the efforts to turn waste into useful products can be achieved through technological advances, such as the replacement of low-degradable products for those easily degraded by microbial action [10].

The paper is comprised of cellulose fibers linked by hydrogen bonds. The formation and quantity of such links in cellulose and its byproducts influence on the physical and chemical properties of such materials [11].

Several studies investigated the cellulose and paper biodegradation. The degradation of Kraft paper under controlled laboratory conditions (based on the maximum measure of $\mathrm{CO}_{2}$ generated) does not exceed $70 \%$ within a 45 day period [12]. Other study was investigated the biodegradability of chitosan for 40 days in a soil experiment by gravimetric analysis [13].

This study has assessed the biodegradability of chitosan film-coated Kraft paper sheets, emulsified chitosan film-coated chitosan sheets, as well as uncoated Kraft paper sheets. In order to assess the biodegradability, analysis on scanning electron microscopy (SEM), gravimetry, soil respiration, microbial biomass carbon and enzymatic soil activity were performed.

\section{MATERIALS AND METHODS}

\subsection{Materials}

The materials used in this work were: Chitosan (Primex, ChitoClear ${ }^{\circledR}$, batch TM 2227, Iceland), acetic acid (Synth, Brazil), palmitic acid (Synth, Brazil), and sheets of Kraft paper with a weight of $200 \mathrm{~g} / \mathrm{m}^{2}$ (Klabin, Brazil).

\subsection{Sample Preparation}

The samples used in this work were: Uncoated Kraft paper sheets (KSR), Kraft paper sheets coated with filmogenic solution of chitosan (KQ), Kraft paper sheets coated with filmogenic solution emulsified of chitosan with palmitic acid coated (KAP).

\subsubsection{Scanning Electron Microscopy}

The KSR, KQ and KAP samples were cut into pieces of $0.25 \mathrm{~cm}^{2}$ and placed inside plastic flasks with $10 \mathrm{~mL}$ of common soil solution and distilled water at a $100 \mathrm{~g} / 1 \mathrm{~L}$ ratio, respectively. The flasks were stored at room temperature and the samples were collected. After each collection, the samples were submerged in a fixative solution. By the completion of the last collection, the samples were dried to "critical point" by the CPD 030-Critical Point Dryer (BALZERS model), and then, it was used an Emitech metalizer. The samples received gold deposition for three minutes under a 25,000 Ampere current, and then had their structure and biofilm formation analyzed by a Gemini Leo 982 (Leica $x$ Zeiss) high resolution scanning electron microscope from the laboratory of environmental microbiology of Brazilian Agricultural Research Corporation-EMBRAPA of under the following conditions: voltage $=10 \mathrm{Kv}$; working distance $=16 \mathrm{~mm}$.

\subsubsection{Gravimetric Analysis}

The gravimetric analysis consists in storing the $\mathrm{KSR}, \mathrm{KQ}$ and KAP samples in nylon bags. The bags were prepared containing about $0.80 \mathrm{~g}$ of samples dried in an oven at $105^{\circ} \mathrm{C}$. Then they were buried in $10 \mathrm{~cm}$ deep common soil furrows (without treatment). In soil, the furrows were moulded by establishing the distance of $40 \mathrm{~cm}$ between samples with similar coating and $100 \mathrm{~cm}$ between different samples (Figure 1). The collections were performed in: $3,7,15$ and 30 days. In each collection, samples were taken off the bags, dried in an oven at $105^{\circ} \mathrm{C}$ and weighted in a Scientech SA 210 analytical balance. The mass of samples that may have been degraded by microorganisms in soil was 
determined by their weight difference. The analyses were performed in triplicate and the results were expressed in grams:

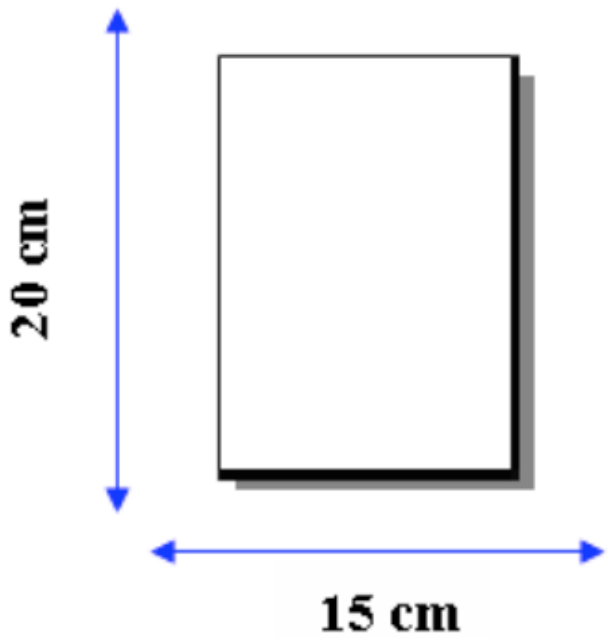

Figure 1: Area of furrow moulded in soil.

\subsubsection{Analysis of Microbial Biomass Carbon and Enzymatic Soil Activity}

The uncoated Kraft paper samples (KSR), chitosan filmogenic solution-coated Kraft paper (KQ), palmitic acid emulsified chitosan solution-coated Kraft paper (KAP), were divided into the following weights: $0.5,2.5$ and $5.0 \mathrm{~g}$; and were stored in nylon bags $110 \mathrm{~cm} \mathrm{x}$ $10 \mathrm{~cm})$. The bags containing the samples were buried in $10 \mathrm{~cm}$ deep common soil furrows (without treatment). In soil, the furrows (Figure 1) were moulded by establishing the distance of $40 \mathrm{~cm}$ between samples with similar concentrations and $100 \mathrm{~cm}$ between samples with different concentrations (Figure 2). The collections were performed in: 7,15 and 60 days for the microbial biomass carbon analysis and 15 and 60 days for the enzymatic soil activity analysis.

\subsection{Methods}

\subsubsection{Solubilization of Chitosan}

The filmogenic solution was obtained by dispersing chitosan $4 \%(\mathrm{w} / \mathrm{w})$ in aqueous acidic solution under continuous stirring. Addition of acetic acid was made from the sample mass, considering the degree of acetylation of chitosan (18\%) to avoid excess acetic acid, or the amount of acetic acid added was stoichiometrically calculated on the basis of the groups glucosamine chitosan present in the molecule.

\subsubsection{Emulsion of Chitosan}

The emulsified filmogenic solution was obtained after preparation of the chitosan solution $(4.0 \% \mathrm{w} / \mathrm{w})$ with the addition of palmitic acid $(2.0 \% \mathrm{w} / \mathrm{w})$ under heating to $\mathrm{T}=90{ }^{\circ} \mathrm{C}$ (temperature above the melting point of the lipid) under continuous stirring. The solution was emulsified in a mechanical stirrer at 5000rpm for 10 minutes.

\subsubsection{Packaging Systems Kraft Paper-Film}

After complete dissolution of chitosan, the solution was distributed into sheets of kraft paper with an area of approximately $0.45 \mathrm{~m}^{2}$, resulting in a concentration equivalent to $3.5 \mathrm{~g} / \mathrm{m}^{2}$ of chitosan coated sheet. The solutions were applied to sheets of Kraft paper, using an extender spiral (TKB Ericksen, Brazil) of $80 \mu \mathrm{m}$. And then were dried for 1 minute at $\mathrm{T}=200^{\circ} \mathrm{C}$.

\subsubsection{SEM (Scanning Electron Microscopy)}

The scanning electron microscopy analysis showed the surface of each samples: KSR, KQ and KAP, (uncoated Kraft paper, Kraft paper coated with chitosan films and Kraft paper coated with films emulsified chitosan films and palmitic acid in crescent time

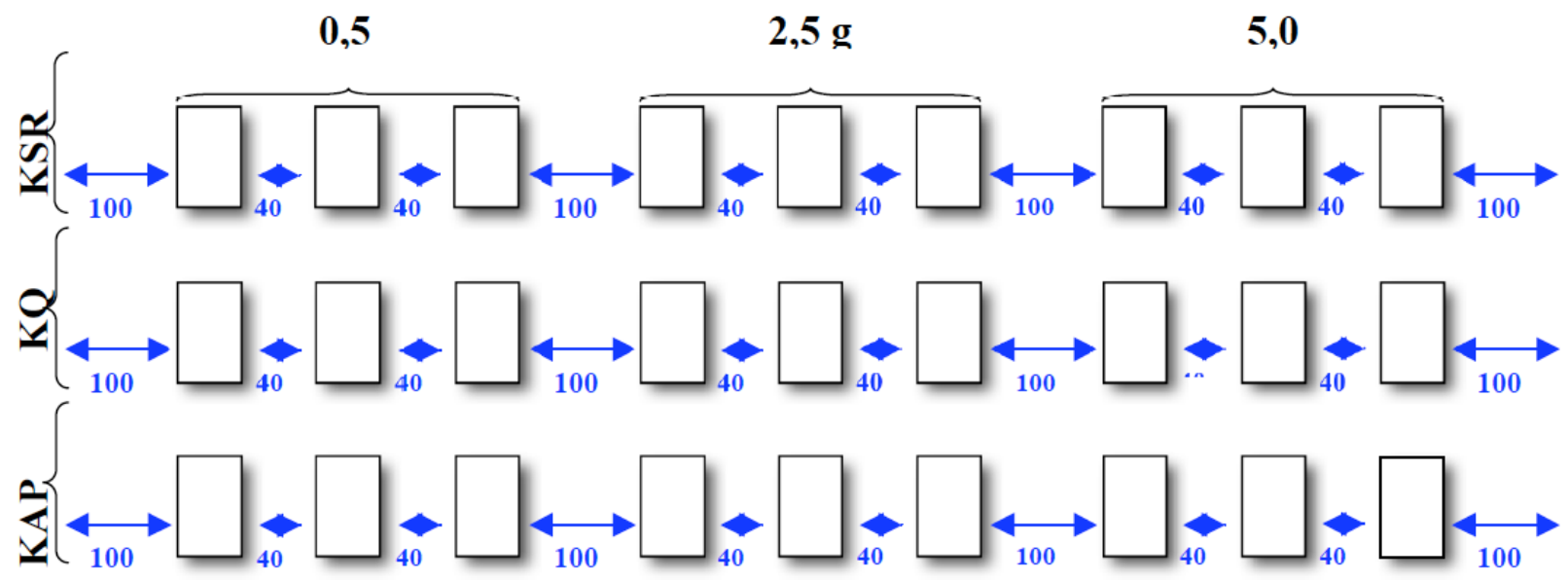

Figure 2: Layout of samples arrangement in soil. 
intervals in order to follow-up the formation of films thoughout the soil microorganisms and to view bacterial colonies.

\subsubsection{Soil Respiration}

The soil respiration analysis was performed based on norm ASTM D5271-92 (1983) [14], and consisted in storing $0.5 \mathrm{~g}$ of each sample (KSR, KQ and KAP) in properly sealed threaded glass flasks containing $100 \mathrm{~g}$ common soil (without treatment) and placing them under light together with glass flasks containing only $100 \mathrm{~g}$ soil (without samples), called 'witnesses'. The $\mathrm{CO}_{2}$ evolution volumetric measure during the respiration process was determined by titration (Eq. 1).

$\mathrm{KOH}+\mathrm{CO}_{2} \rightarrow \mathrm{K}_{2} \mathrm{CO}_{3}+\mathrm{H}_{2} \mathrm{O}$

\subsubsection{Gravimetry Analysis}

The gravimetric analysis of soil degradation in soil was performed based on guideline NBR 10.004 (ABNT, 1987) [15], and consisted in the difference of mass of the samples buried in soil (initial weight) and the samples weight after a certain period (final weight). The collections were performed at: 3, 7, 15 and 30 days for the KSR, KQ and KAP samples (Table 1).

\subsubsection{Microbial Biomass Carbon}

The microbial biomass carbon analysis was performed based on the fumigation-extraction method [16], in which the microbial biomass is estimated by the difference of $\mathrm{CO}_{2}$ flow of soil samples fumigated with chloroform (F) and those non-fumigated (NF) (Figure 3).

\subsubsection{Microbial Biomass Carbon and Soil Respiration}

Altogether, the microbial soil biomass is directly related to the carbon amount (substrate) in the soil [17].
The microbiological activity, like every reaction catalyzed by soil microorganisms, reflects the physiological state of active cells and can be divided into general and specific activity. The general activity is that performed by almost all soil microorganisms as respiration [17].

Soil respiration is one of the most antique variables used to quantify microbial activity [18] and is positively related to the organic matter content and microbial biomass [19].

The combination of microbial biomass measures and soil respiration provide the amount of $\mathrm{CO}_{2}$ evolved per biomass unity and is known as metabolic or respiratory coefficient $\left(\mathrm{qCO}_{2}\right)$. The $\mathrm{qCO}_{2}$ indicates the microbial biomass efficiency to use the carbon available for biosynthesis [20]. In this work, a study relating the microbial biomass carbon and soil respiration was conducted, in which the samples (KSR, $\mathrm{KQ}$ and KAP) were buried and stored, respectively.

\subsubsection{Enzymatic Soil Activity}

The enzymatic soil activity was determined by the quantification of $\beta$-glucosidase and endoglucanase activities in soil, related to the carbon cycle. The first one was related to the completion of the cellulose decomposition process [21]. The enzymatic soil activity analysis was based on the Schinne and Von Mersi (1990) method, in which $5 \mathrm{~g}$ soil in a $2 \mathrm{~mm}$ sieve were incubated in acetate buffer and carboxymethylcellulose $(0.7 \% \mathrm{w} / \mathrm{w})$ for $24 \mathrm{~h}$ at $50^{\circ} \mathrm{C}$ using Cientec CT-281 ultrathermostatic shower. By the completion of the incubation period, the suspension was filtered and $1 \mathrm{~mL}$ was taken from the filtrate. The part was divided in threaded flasks, in which dilutions for $20 \mathrm{~mL}$ by distilled water were performed. From dilution $1 \mathrm{~mL}$ was taken and reagents $A$ and $B$ were added. Then, the samples
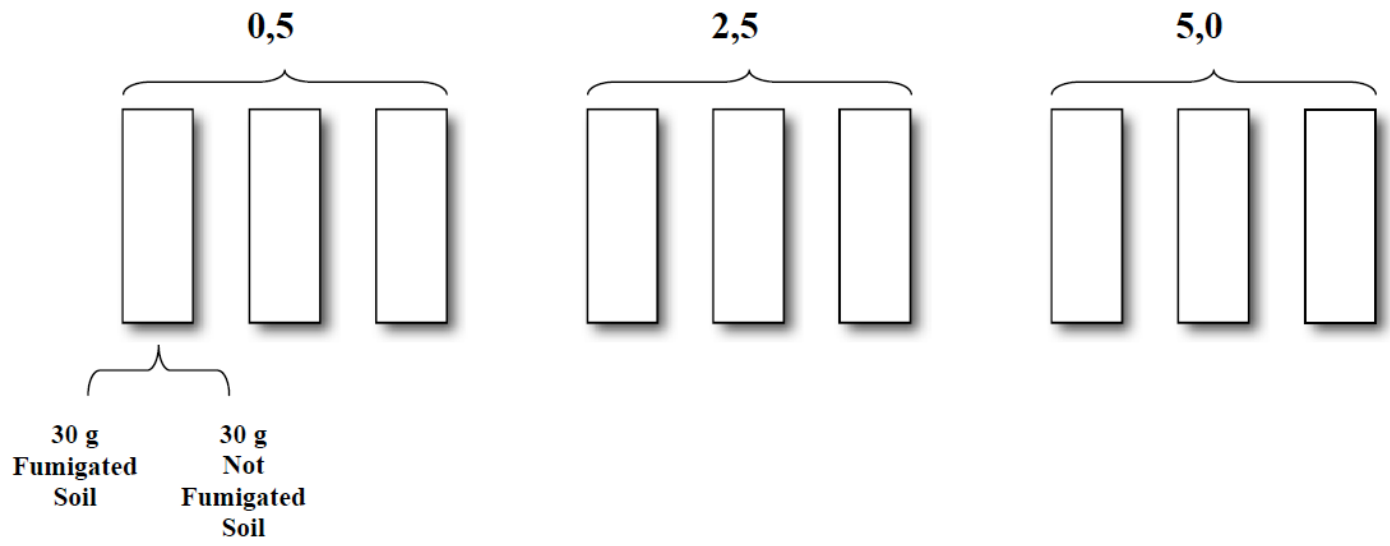

Figure 3: Arrangement of samples for analysis on microbial biomass carbon. 
were put into water bath at $100^{\circ} \mathrm{C}$ for 15 minutes and then put into cooling bath at $20^{\circ}$ for 5 minutes. Then, to each threaded tube $5 \mathrm{~mL}$ reagent $C$ were added and put in rest for 60 minutes in order to develop the color. The reading was performed with a Shimadzu UV$1601 \mathrm{PC}$ spectrophotometer at $690 \mathrm{~nm}$. Analysis were performed in triplicate and the calculations to determine the glucose quantity per gram of dry soil $\mu \mathrm{g} \mathrm{soil}{ }^{-1} .24 \mathrm{~h}^{-1}$ was performed according to equation 2 .

Reagent A - $16 \mathrm{~g}$ sodium carbonate (anhydrous) were dissolved in distilled water and $0.9 \mathrm{~g}$ potassium cyanide were added (it was performed $1000 \mathrm{~mL}$ dilution with distilled water).

Reagent $B-0.5 \mathrm{~g}$ ferric potassium hexacyanide were dissolved in distilled water and increased to $1000 \mathrm{~mL}$ in volume (ps: store in amber flask).

Reagent $C-1.5$ ferric sulfate of ammonia were dissolved together with $1 \mathrm{~g}$ dodecyl sulfate of sodium and $4.2 \mathrm{~mL}$ sulfuric acid concentrated in distilled water at $50^{\circ} \mathrm{C}$. A in distilled water. The solution was increased $1000 \mathrm{~mL}$ in volume with distilled water.

$\frac{\mu \text { g.glicose }}{\text { g.solo.secoem } 24 h r s}=\frac{C^{*} V^{*} t}{S w^{*} d w t}$ where,

$\mathrm{C}=$ concentration of glucose $/ \mathrm{mL}$ of filtrate $(1 \mathrm{~mL})$

$V=$ test suspension volume (at the $30 \mathrm{~mL}$ system)

$\mathrm{t}=$ dilution factor $(20 \mathrm{~mL}$ for agriculture soil $)$

Sw $=$ weight of soil sample used ( $5 \mathrm{~g}$ soil)

$d w t=$ incubation time $(24 \mathrm{~h})$.

\section{RESULTS AND DISCUSSION}

\subsection{SEM (Scanning Electron Microscopy)}

To better understand the biodegradability of the Kraft paper coated with natural material it is extremely important to evaluate some scientific paramethers because there are few data available on the subject. The greater evidence of biofilm formation was seen in the $\mathrm{KQ}$ samples (8h), what may be related to the beginning of the paper degradation process in soil. It was possible to visualize a greater formation of bacterial cells in the $K Q$ samples after $72 \mathrm{~h}$, indicating that the chitosan film coating acted a substrate for the cellular reproduction, also noticed by the increase of bacterial cell formation during the collection periods when compared to the KSR samples (times: 3, 8, 12

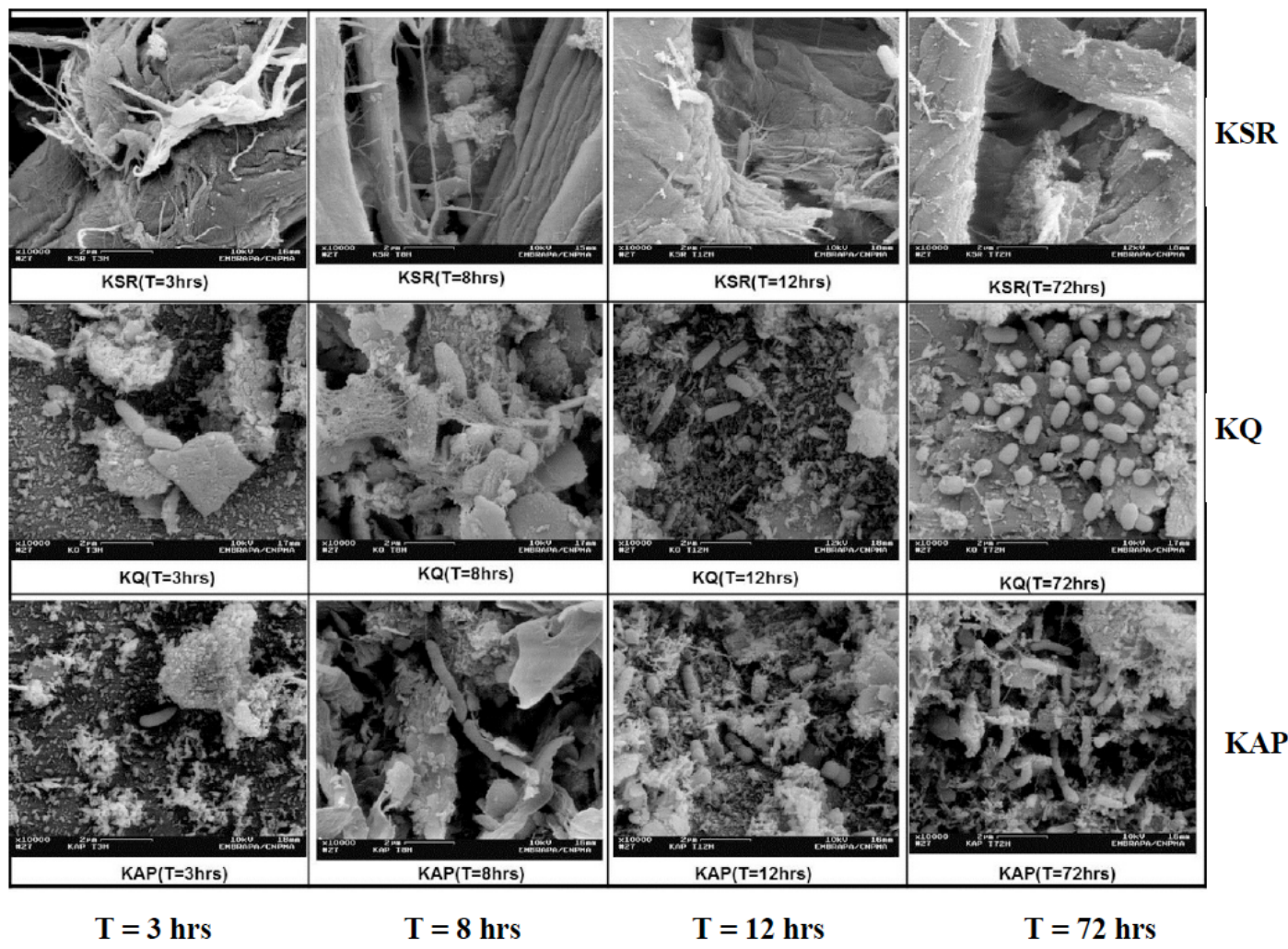

Figure 4: SEM pictures of Kraft paper sheets: KSR, KQ and KAP. 
and 72 hours). The KAP samples had a similar behavior to the $K Q$ samples. As the number of cells increased, the times of collection were increased (Figure 4).

\subsection{Gravimetric Analysis}

In the gravimetric analysis of soil degradation was the collections were performed at: 3, 7, 15 and 30 days for the KSR, KQ and KAP samples (Table 1).

It was observed in all samples the gradual reduction of masses in relation to the times of collection and even more in the degradation behavior regarding the $K Q$ and KAP samples (Figure 5).

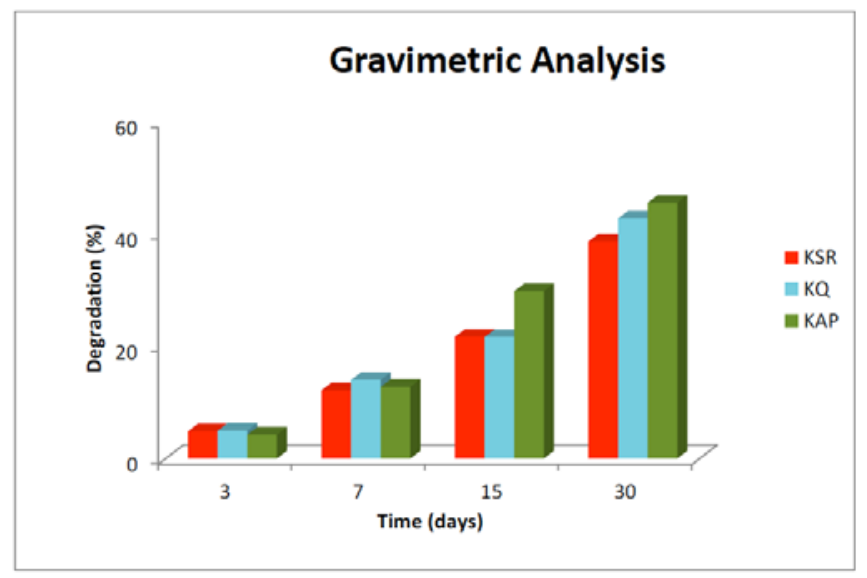

Figure 5: Percentage graph of the degradation of $\mathrm{KSR}, \mathrm{KQ}$ and KAP systems under gravimetric soil analysis.

The difference of masses could also be noticed by the degradation percentage, which confirmed the greater degradation. The KSR, KQ and KAP samples presented increasing degradation percentage of 38,42 and $45 \%$ in 30 days (Table 1 ).

Table 1: Percentage of Degradation of the KSR, KQ and KAP Systems under Gravimetric Soil Analysis

\begin{tabular}{|c|c|c|c|c|}
\hline Time (days) & $\mathbf{3}$ & $\mathbf{7}$ & $\mathbf{1 5}$ & $\mathbf{3 0}$ \\
\hline \hline KSR & 4.84 & 12.10 & 21.57 & 38.54 \\
\hline KQ & 4.96 & 13.94 & 21.52 & 42.80 \\
\hline KAP & 4.24 & 12.70 & 29.68 & 45.62 \\
\hline
\end{tabular}

\subsection{Soil Respiration}

In the soil respiration analysis performed with $0.5 \mathrm{~g}$ of each sample: KSR, KQ and KAP; during the 15 days interval of material incubation in soil, as shown in Figure 6, the increase of microbial activity can be observed.

\section{Soil Respiration}

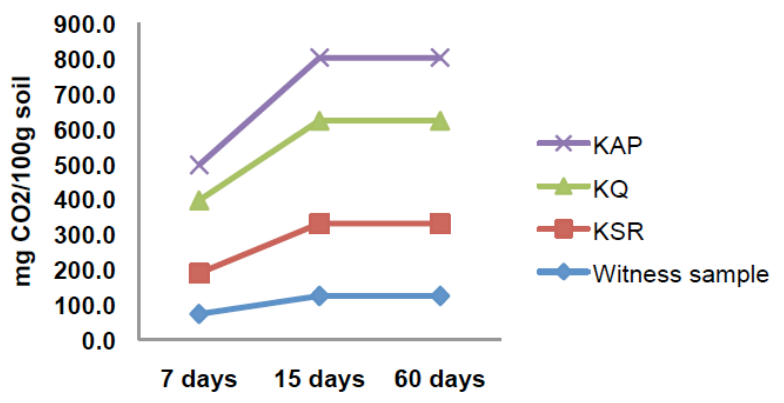

Figure 6: Soil respiration analysis graph.

In Figure 6, the curve relative to the control corresponds to white, landmark, therefore, to the glass flasks that contained only $100 \mathrm{~g}$ soil, without no stored samples. The respiration increased in all systems at the first 15 days. The increase of respiration in descending order for the KQ, KSR and KAP samples (Figure 6).

The KSR system, as expected, presented remarkable cellulose content, increasing the microbial activity observed by the increase of its respiration when compared to the control.

In the system KAP did not occur high respiration, suggesting that the presence of lipid at the emulsified filmogenic matrix promote an increase of the microbial community metabolism in the soil sample. It is possible to conclude that the junction of Kraft paper to the emulsified filmogenic matrix had been stabilized in this metabolism.

\subsection{Microbial Biomass Carbon}

In the Microbial Biomass Carbon (MBC) performed with the KSR, KQ and KAP samples in the 0.5, 2.5 and $5.0 \mathrm{~g}$ masses, the term control was used to identify the white, reference point and, therefore, the soil samples in which no analyzed samples were buried (Figure 7).

It was reported in the $\mathrm{KAP}$ and $\mathrm{KQ}$ samples the inhibition of the microbial activity at the first 7 days, which has been restored from the $15^{\text {th }}$ day.

The KSR samples, within the 7 day collection period, presented an increase of microbial biomass carbon with significant statistical differences between the witness soil and the samples with $0.5,2.5$ and $5.0 \mathrm{~g}$ mass. However, there were no changes in the microbiota and consequently there were no changes in the samples degradation process. Within the 15 days 

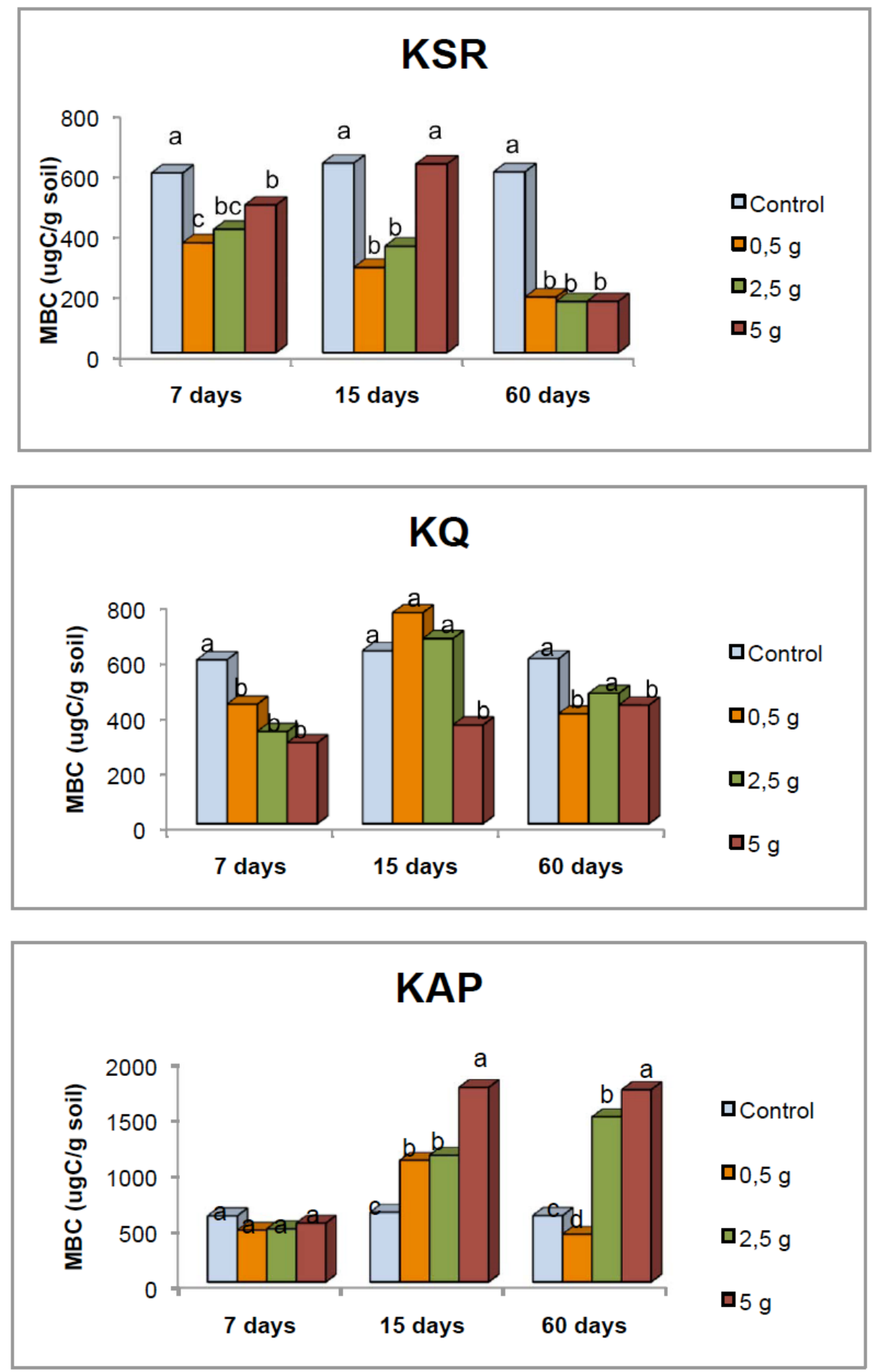

Figure 7: Microbial biomass carbon analysis of the KSR, KQ and KAP systems' (a) $0.5 \mathrm{~g}$, (b) $2.5 \mathrm{~g}$, (c) $5.0 \mathrm{~g}$ masses.

collection period, there were no significant statistical differences between the control witness soil and the $5.0 \mathrm{~g}$ samples, indicating that a greater the presence of Kraft paper, when compared to the 0.5 and $2.5 \mathrm{~g}$ samples. However, this $5.0 \mathrm{~g}$ sample presented an increase within the 7 day collection period, indicating an increase in the KSR samples degradation process. Within the 60 day collection period, there were significant statistical differences between the control witness soil and the $0.5,2.5$ and $5.0 \mathrm{~g}$ samples, indicating a reduction of microbial biomass carbon and consequent organic matter decrease and a period of greater microbial activity within the 15 days period.

In the KQ samples, within the 7 days collection period, there were no significant statistical difference 
Table 2: Comparison between the Percentage of Increase and Reduction of the Microbial Biomass Carbon and Soil Respiration Analysis of the KSR, KQ and KAP Samples

\begin{tabular}{|c|c|c|c|c|}
\hline \multirow{2}{*}{ Samples } & \multicolumn{2}{|c|}{ MBC $(\mu \mathrm{C} / \mathrm{gsoil})$} & \multicolumn{2}{c|}{ Respiration $\left(\boldsymbol{\mu C O} \mathbf{C}_{2} / \mathbf{1 0 0 g s o i l )}\right.$} \\
\cline { 2 - 5 } & from 7 to 15 days & from 15 to 30 days & from 7 to 15 days & from 15 to $\mathbf{3 0}$ days \\
\hline \hline $\mathrm{KSR}$ & $-22.32 \%$ & $-34.92 \%$ & $+76.59 \%$ & Stable \\
\hline $\mathrm{KQ}$ & $+76.29 \%$ & $-47.90 \%$ & $+41.91 \%$ & Stable \\
\hline $\mathrm{KAP}$ & $+135.74 \%$ & $-60.87 \%$ & $+78.15 \%$ & Stable \\
\hline
\end{tabular}

$(+)=$ increase $;(-)=$ reduction .

$\mathrm{MBC}=$ microbial biomass carbon

between the 0.5, 2.5 and $5 \mathrm{~g}$ samples when compared one to another. However, they presented significant statistical difference when compared to the witness soil, indicating that there was no increase in microbial biomass carbon. Therefore, there were no changes in the $\mathrm{KQ}$ samples degradation process. Within the 15 day collection period, there were no significant statistical difference between the $0.5,2.5$ and $5 \mathrm{~g}$ samples when compared to the witness soil. However, there were significant statistical differences when compared to the $5.0 \mathrm{~g}$ samples, indicating microbial activity reduction. Within the 60 days collection period, there were no significant statistical differences between the $0.5,2.5$ and $5.0 \mathrm{~g}$ samples when compared one to another. However, when they were compared to the witness soil, the 0.5 and $5.0 \mathrm{~g}$ samples presented significant statistical differences and reduction in microbial activity, indicating that there was no organic matter in the soil, indicating that the period of greater microbial activity occurred at the 15 days interval.

In the KAP samples, within the 7 day collection period, there were no significant statistical difference between the $0.5,2.5$ and $5 \mathrm{~g}$ samples when compared one to another and to the witness soil. Within the 15 day collection period, there were significant statistical difference between the $0.5,2.5$ and $5 \mathrm{~g}$ samples when compared one to another and to the witness soil. Such difference was greater for the $5.0 \mathrm{~g}$ sample, indicating an increase of biomass carbon. This increase also corresponded to an increase of organic matter and consequently to an increase in the degradation of KAP samples in soil. Within the 60 day collection period, there were significant statistical difference between the $0.5,2.5$ and $5 \mathrm{~g}$ samples when compared one to another and to the witness soil. Such difference was greater for the $5.0 \mathrm{~g}$ sample, once again indicating the increase of degradation of KAP samples in soil.

\subsection{Microbial Biomass Carbon and Soil Respiration}

The microbial biomass carbon and soil respiration are interlinked, since the steady respiration behavior of a certain soil sample corresponds to a reduction of biomass carbon (Figure 8 ).

The comparative analysis of the $\mathrm{MBC}$ and soil respiration analysis, performed in the $K S R, K Q$, and KAP samples, showed the reduction and relative increase when compared to both analysis (Table 2).

The KSR sample, at the 7 from 15 days collection interval, reduced $22.23 \%$ in CBM and increased $76.59 \%$ in soil respiration. Within the 60 days collection interval, the KSR sample had its MBC reduced about $34.92 \%$ and the respiration analysis remained stable, indicating that when there was no more microbial activity, there was heat of the microorganism's respiration that indicates consistency in the analysis.

The KQ sample, within the 7 to 15 day collection interval, had its MBC increased about $76.29 \%$ and at the same time presented $49.91 \%$ soil respiration. Within the 15 to 60 day collection interval, the $\mathrm{KQ}$ sample had its MBC reduced about $47.90 \%$ and the respiration remained stable, indicating that as the respiration stabilized, the $M B C$ reduced.

In Figure 8, the KSR samples present $22.32 \%$ reduction of Microbial Biomass Carbon up to 15 days and $34.92 \%$ from 15 to 30 days.

The samples had a microbial biomass carbon increase of: KQ (76.29\%), KAP (135.74\%); however, the KAP samples presented a great increase than the other samples, what can be due to the presence of lipid in the composition of films applied as coating in Kraft paper sheets.

\subsection{Enzymatic Soil Activity}

The degradability of samples was assessed by the enzymatic soil activity, where the KSR, KQ and KAP samples were buried. The experiments were aimed to determined the enzymatic activity of cellulase enzyme. The increased production of cellulase by 

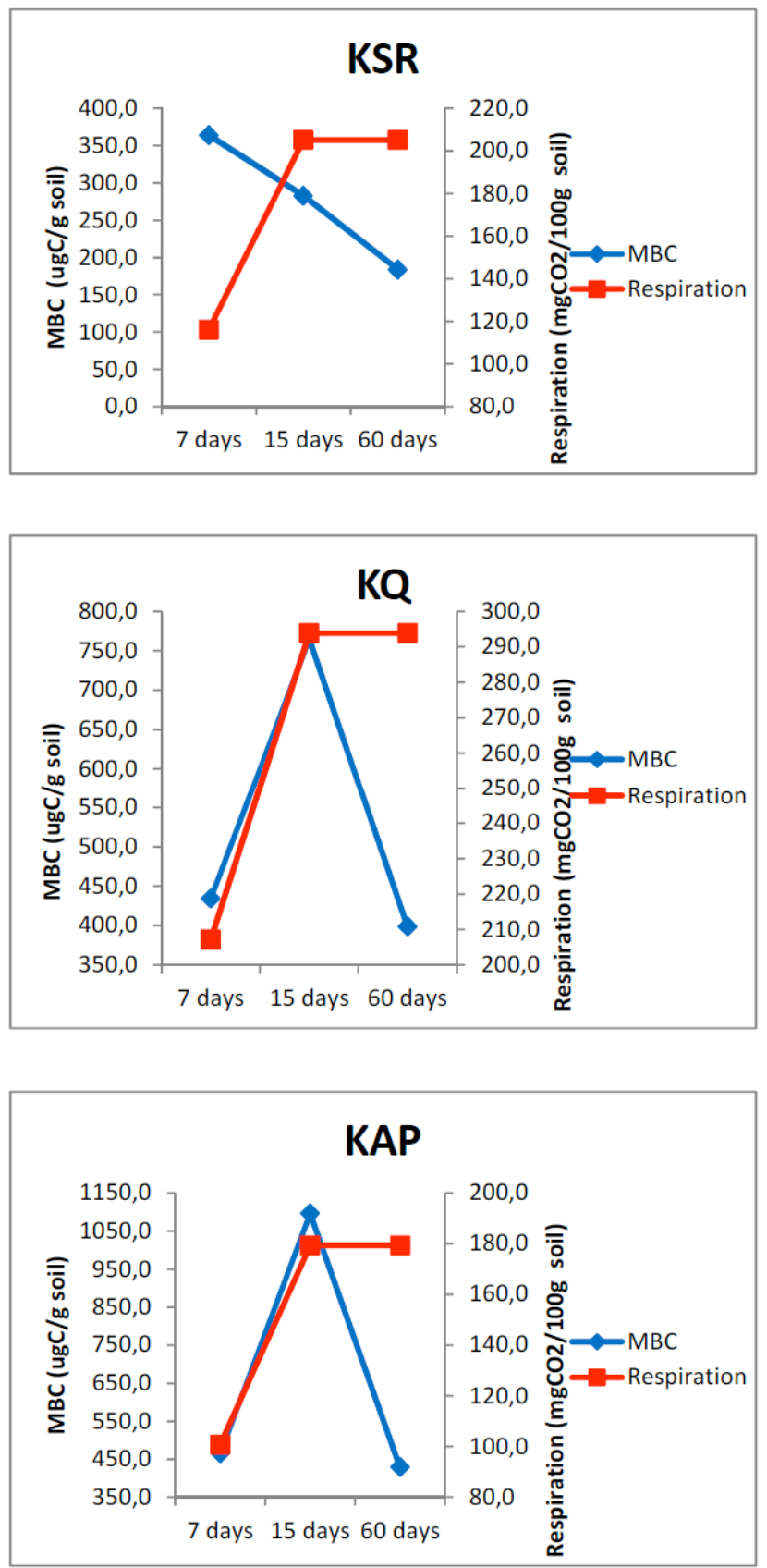

Figure 8: Soil respiration and Microbial Biomass Carbon using $0.5 \mathrm{~g}$ of material of the (a) KSR, (b) KQ and (c) KAP.

microorganisms was observed more closely in the soil samples in which the KSR and KQ samples were buried in 15 days with $5.0 \mathrm{~g}$ sample mass (Figure 9).

The soil is a complex system, shared by beings of different species interacting one with the other and with the soil constituents.

\section{CONCLUSIONS}

- It was possible to see in MEV analysis the formation of microbial biofilms in $8 \mathrm{~h}$ in $\mathrm{KQ}$

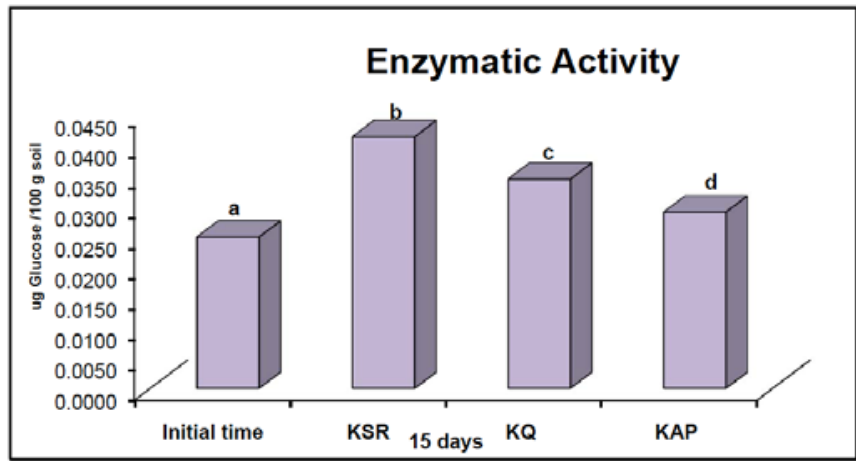

Figure 9: Enzymatic activity of $\mathrm{KSR}, \mathrm{KQ}$ and $\mathrm{KAP}$ samples.

samples, and during the collecting periods $(3,8$, 12 and $72 \mathrm{~h}$ ) it was possible to see the gradual growth of $\mathrm{KQ}$ and $\mathrm{KAP}$ bacterial cells when compared to the KSR samples, indicating that the chitosan film and emulsified chitosan-based coatings act as a substrate to the microorganisms, inducing their growth.

- The KSR, KQ and KAP samples presented increasing degradation percentage of 38,42 and $45 \%$ in 30 days and 62,67 and $49 \%$ in 60 days, indicating that they were degraded.

- The respiration increased in all systems at the first 15 days. The increase of respiration was accented for the KSR, SQ and KAP systems in descending order.

- It was reported in the KAP and KQ samples the inhibition of the microbial activity at the first 7 days, which has been restored from the 15th day. Among the samples studied, it was observed the increased of carbon in microbial biomass, showing an increase in microbial activity in soil at the first 15 days, mainly in KAP.

- The increased production of cellulase by microorganisms was observed more closely in the soil samples in which the $K S R, K Q, F Q$ and FAP samples were buried in 15 days with $5.0 \mathrm{~g}$ sample mass.

- The increased production of cellulase by microorganisms was observed more closely in the soil samples in which the KSR, KQ samples were buried in 15 days with $5.0 \mathrm{~g}$ sample mass.

\section{ACKNOWLEDGEMENTS}

We thank Fapesp, CNPq, CAPES, for the financial support and EMBRAPA - Environmental. 


\section{REFERENCES}

[1] Flieger M, Kantorová M, Prell A, Rezanka T, Votruba J. Biodegradable Plastics from Renewable Sources. Folia Microbiol 2003; 48(1): 27-44. http://dx.doi.org/10.1007/BF02931273

[2] Massadier-Nageotte V, Pestre C, Cruard-Pradet T, Bayard R. Aerobic and anaerobic biodegradability of polymer films and physico-chemical characterization. Polymer Degradation Stability 2006; 91: 620-27.

http://dx.doi.org/10.1016/j.polymdegradstab.2005.02.029

[3] Zuideveld M, Gottschalk C, Kropfinger H, Thomann R, Rusu $\mathrm{M}$, Frey $\mathrm{H}$. Miscibility and properties of linear poly $(\mathrm{L}-$ lactide)/brenched poly(L-lactide) copolyester blends. Polymer 2006; in press.

[4] Shangguan Y-Y, Wang Y-W, Wu Q, Chen G-Q. The mechanical properties and in vitro biodegradation and biocompatibility of UV-treated poly(3-hydroxybutyrate-co-3hydroxyhexanoate). Biomaterials 2006; 27: 2349-57. http://dx.doi.org/10.1016/j.biomaterials.2005.11.024

[5] Ohtake Y, Kabayashi T, Asabe H, Murakami M. Studies of biodegradation of LDPE - observation of LDPE films scattered in agricultural fields or in garden soil. Polymer Degradation Stability 1998; 60: 79-84.

http://dx.doi.org/10.1016/S0141-3910(97)00032-3

[6] Melo, Itamar Soares De. Microbiologia Ambiental. 2 ${ }^{\underline{a}}$ ed. Embrapa Meio Ambiente - Jaguariúna/SP 2008.

[7] Muzzarelli RAA. Chitosan-based dietary foods. Carbohydrate Polymers 1996; 29: 309-16. http://dx.doi.org/10.1016/S0144-8617(96)00033-1

[8] John MJ, Thomas S. Biofibres and biocomposites. Carbohidrate Polymers 2008; 71: 343-64. http://dx.doi.org/10.1016/j.carbpol.2007.05.040

[9] Peter MG. chitin and chitosan from animal sources. In: Biopolymers, Polyssaccharides II: Polissaccarides from Eukaryotes, (A. Steinbüchel series ed. Vandamme EJ, De Baets S, Steinbüchel A, Eds. Weinheim: Wiley-VCH 2002a; vol. 6: pp. 481-574.

[10] Van Wyk JPH, Mohulatsi M. Biodegradation of waste cellulose. J Polym Environ 2003; 11(1). http://dx.doi.org/10.1023/A:1023883428359
[11] Kondo T, Koschella A, Heublein B, Klemm D, Heinze T. Hydrogen bond formation in regioselectively functionalized 3mono-O-methyl cellulose. Carbohydrate Res 2008; 343: 2600-2604

http://dx.doi.org/10.1016/j.carres.2008.06.003

[12] Alvarez JVK, Larrucea MA, Bermúdez PA, Chicote BL. Biodegradation of paper waste under controlled composting conditions. Waste Management 2009; 19: 1514-19. http://dx.doi.org/10.1016/j.wasman.2008.11.025

[13] Kuo PC, Sahu D, Yu HH. Properties and biodegradability of chitosan/nylon 11 blending films. Polymer Degradation Stability 2006; 91: 3097-102. http://dx.doi.org/10.1016/j.polymdegradstab.2006.07.025

[14] ASTM (American Society for Testing and Materials) (1993) in 1993 Annual Book of ASTM Standards, volume 08.03, D5271-92, Philadelphia, Pensylvania, ASTM 1983; pp. 411416.

[15] ABNT Associação Brasileira de Normas Técnicas - Sistema Nacional de Metrologia, Normalização e Qualidade Industrial, NBR 10.004-Classificação de Resíduos Sólidos. ABNT 1987.

[16] Vance ED, Rookes PC, Jenkinson DS. An extraction method for measuring soil microbial biomass C. Soil Biol Biochem Oxford 1987; 19: 703-707. http://dx.doi.org/10.1016/0038-0717(87)90052-6

[17] Moreira FMS, Siqueira JO. Microbiologia e bioquímica do solo. Lavras: UFLA 2002; p. 626

[18] Lopes EBM. Diversidade Metabólica em solo tratado com biossólidos. Dissertação de Mestrado (Agronomia, área de concentração: Solo e nutrição de plantas) -Escola Superior de Agricultura Luiz de Queiroz, USP, Piracicaba 2001.

[19] Alef K, Nannipieri P. Methods in applied soil microbiology and biochemistry. Londres: Academic Press 1995; p. 576

[20] Saviozzi A, Bufalino P, Levi-Minzi R, Riffald R. Biochemical activities in a degraded soil restored by two amendments: a laboratory study. Biol Fertility Soils Berlim 2002; 35: 96-101.

[21] Matsuoka M Mendes IC, Loureiro MF. Biomassa microbiana e atividade enzimática em solos sob vegetação nativa e sistemas agrícolas anuais e perenes na região de primavera do leste (MT). R Brás Ci Solo 2003; 27: 425-33.

Received on 12-03-2013

Accepted on 15-05-2013

Published on 26-06-2013

DOI: http://dx.doi.org/10.6000/1929-5995.2013.02.02.6

(C) 2013 Reis et al.; Licensee Lifescience Global.

This is an open access article licensed under the terms of the Creative Commons Attribution Non-Commercial License (http://creativecommons.org/licenses/by-nc/3.0/) which permits unrestricted, non-commercial use, distribution and reproduction in any medium, provided the work is properly cited. 